\title{
I. 微生物分類学の動向
}

駒形和男

東京大学応用微生物研究所

(1)

微生物の分類の研究は微生物学の初期の頃から微生物 研究者の関心を呼んた゚問題である. しかし, 形態に基礎 を置く動物や植物の分類に比へ，形態の簡単な微生物の 分類は自ずとこれらの生物の分類と異なる途を歩まざる を得なかった. 特に, 人をはじめ動物や植物の病気の原 因となる細菌はこれらの生物との関わりから研究されて

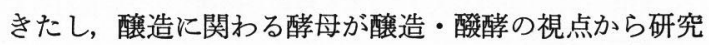
されてきたことも事実である. 微生物の分類の研究は人 の生活と密接に関わりながら発達してきたので, その分 類体系も目的指向型といえよう. したがって, 医学の分 野では病原菌をできるだけ速く分離・同定することに力 が注がれ, 応用の分野では醸造や醈酵の優等生の選抜に 目が向けられた. また，今から 100 年ほど前微生物学が 開花した時代には, 微生物の種 (species) の概念も明確 でなく, 分離した一株一株を区別するために学名をつけ ていたと考えられ, その種の違いも現在の知識からすれ ば菌株の違いに相当するものもあったと思われる.

一方, 土壤中の細菌に注目した研究者たちは硝化菌, 根粒菌, Azotobacter などの分離に成功し, 無機栄養細 菌の存在を明らかにした. この研究はオランダのデルフ ト学派による微生物の多様性の研究に発展し, 微生物が ぞのような生物であるかといら観点からの研究がなされ るようになった. ちなみに, 1800 年代の後半から 1900 年代の前半にわたり, 窒素固定菌, enrichment culture など, 多彩な微生物の研究を行ない, General Microbiology の基礎を築いた Beijerinck を, 彼の後継者であ るデルフト工科大学の Kluyver は次のように紹介して いる(1).

"Beijerinck undoubtedly wished to emphasize that the study of micro-organisms not only calls for special techniques quite foreign to the science of the higher organisms, but also a special intellectural and mental outlook which is only

gradually gained by a continued occupation with microscopic life".

このようにして, 微生物に関する理解が次第に深まっ てきたものと思われる。

その後, 微生物分類学は他の科学の研究の発展と相ま って急速に変貌をとげ, 特に新しい分類システム, 命名 規約の改定，同定のための新しい性状の採用，試験方法 の改変,さらに微生物の系統などについて多くの報告が なされている.したがって, 微生物の分類学的研究は以 上のことを正しく認識して行なわねばならないまた， 正しい学名の使用は, 研究上も, 特許上も必須のことで ある.このよらな観点から，本シリーズでは微生物分類 学に関する最近の動向をそれぞれの専門分野ごとに述べ てゆくこととする.

\section{微生物の分類・命名・同定および系統}

微生物の分類学に和いて, 分類, 命名, 同定および系 統といら用語は, しっかりと定義され, その定義に従っ て用いられてこなかったように思われる. 微生物学の成 書の記述から微生物分類学で用いられている用語の意味 を明確に理解しようとしても，なかなか困難である. そ れは, 細菌学がその出発の時点から人の医療の分野から 発達し, 酵母の研究が醸造を安定させる観点から, また 菌類の研究が植物学の研究に根ざし, 微生物としての共 通の地盤に立脚していなかったためと考えられる. しか し, 電子顕微鏡および観察技術の発達は微生物どうしの 細胞の微細構造の違いを明らかにし, 分子生物学, 遺伝 学, 生化学および関連分野の発達は生物の遺伝を司る物 質的基礎は DNA にあることを明らかにするとともに， 遺伝情報の発現についても詳しい機構の解明をした. そ の結果, 微生物の相互関係を分子のレベルで研究するこ とができるようになったまをた，核酸や蛋白質のような 
情報高分子の研究は, 従来進化や系統の明らかでなかっ た微生物を時間のパラメータを用いた系統樹で表わすこ とを可能とした. これらの研究は, やや子すれば歴史的 背景からその特殊性のみを強調してきた細菌の分類学や 菌類の分類学に微生物分類学としての共通の基盤を与兄 る結果となり，微生物として一括されている微小な生物 がどのような点で共通であり，ぞの点に扔いて異なって いるかといらことが明らかになりつつある。として，よ うやく同じ用語で共通の認識が得られるようになってき た。次に, 微生物分類学を構成するエレメントについ て，筆者の私見をまじえて述べることとする．

\section{1. 分類 (classification)}

微生物分類学の最小の単位は種 (species) であり, そ の集合が属 (genus), 科 (family) という上位分類群に まとめられていくのが分類の考兄である. この順序を変 えることはできないが，それぞれの種や属にどれだけの 広がりをもたせるかは研究者の見解によるもので，概念 的にはまとまりがあるが，これといった一つの決まりが あるわけではない、すなわち，きわめて主観的である。 微生物どうしが近い関係にあるかどらか考光る場合, 細 胞形態や生活環の似ているものが近いと考兄てもよいし， 特定な生理・生化学的性質をもつものが近い関係沈る と考觉ても差し支えない。こで言う“近い関係”もか なり漠然としている. 分類は分類学上の単位を岗る考光 によって順序よく配列し，体系化することであるから， その考えに絶対的なるのはない，先に述べた“近い関 係”を何に求め，それを今まで得られている情報とい かに組み合わせ，最も信頼される分類群 (taxon) を確 立し，さらに多くの人々に役立つ分類体系を構築するか が，微生物分類学潐わるものの一つの仕事である.

な拉, 微生物の分類を支える, 微生物の系統について は後に述べることとする．微生物の分類に関する最近の 研究として化学分類や数值分類が考兄られるが，これら の詳しいことは本ンリーズで別の著者が述べる.

\section{2. 命名 (nomenclature)}

人類が狩猟生活を送っていた時代，動物を識別し，そ の習性を知り，食糧となる動物を獲り，その情報を伝え るために, 動物に名をつけることは重要な生活手段であ った、しかし，その名のつけ方は，部落により，また部
族により使用する言語も異なっていた。 そこで 18 世紀 の中頃, Linné は生物種の命名に二命名法を考案し, こ れを適用することにより生物種の情報を伝達する途を開 いた. Jefferi は生物の命名について, 次のように述べて いる(2).

"The purpose of names is to act as vehicles of communication. .......Names, however, communicated, should immediately and unequivocally call to mind the concepts intended by transmitter of the names".

微生物の命名は国際命名規約に従わねばならないが, 適用される命名規約はそれぞれの微生物群により異なっ ている。すなわち、細菌，放線菌は国際細菌命名規約 に, 酵母を含さ菌類, 藻類は国際植物命名規約に, 原生 動物類は国際動物命名規約によらねばならない。これら の命名規約はそれぞれ独立である。微生物の命名法は国 際的な約束事で峁って, 一学会, 一国だけの問題ではな く, この約束事を守らない場合, 分類学上の提案, たと 壳ば新種の発表も国際的に認められないことになる。こ れらの詳しいことは別の著者が述べる.

な掠，微生物 (microbes) といら言葉は, 1878 年, フ ランスの軍医学校の Sedillot という外科の教授が初めて 提案したといわれている. その当時, Pasteur が “vegetaux cryptogames microscopiques", "animalculos", "champigons", "infusoria", "torulacees", "bacteries", "vibrioniens", "monads", "mucor", “mucedineese", “levure”などと呼んでいたものを一括して，現在用いら れている微生物という意味に用いたのが始まりといわれ ている.

\section{3. 同定 (identification)}

同定とは, 分類と命名の実際的な応用であって, 分離 株の性状を検査し，それをすでに性状が明らかにされて いる既知の種の性状と比較して，既知のものか，未知 のものか決定することである，同定は菌株を互いに区別 するといら点に意味があり，また迅速に同定するため に，区別する性状に重みをつけるのが普通である，しか し，この性状は系統や進化を反映しているとは限らな い. 同定のための新しい技法は絶兄ず発表され，改良さ れている. また, 使用便利な乾燥培地が市販され, 細 菌なぞの簡易同定キットは実際の同定に役立っている. しかし，簡易同定キットは適用できる種の範囲が決まっ 
ているから，その適用を䛊らないようにしなければなら ない。一方, 多数の性状を等価に扱い,コンピニーター を用いて確率的に菌株を同定する方法もある。微生物分 類学へのコンピューターの導入は別の著者が述べる予定 である、また，化学分類学的性状のうち，その性状が安 定であり，分析が容易であるものは，同定の性状として 用いられている，たとえば，菌体脂肪酸組成，キノン系 などがそれである. しかし, 微生物株の同定は, 最も少 ない検查項目で，簡単でしかも技術的に確立された方法 により，短時間に，正確な結果が得られるのが，最も優 れた方法と考兄られるので, 試験性状の選定には多数の 菌株についての情報があり，化学分類学的情報などとの 相関があるものが望ましい，いずれにせよ，菌株の同定 には研究者の不断の勉強と深い経験がものをいうことを 肝に銘じておくべきである.

\section{4. 系統 (phylogeny)}

系統とは, 生物間の進化的関係 (evolutionary rela-

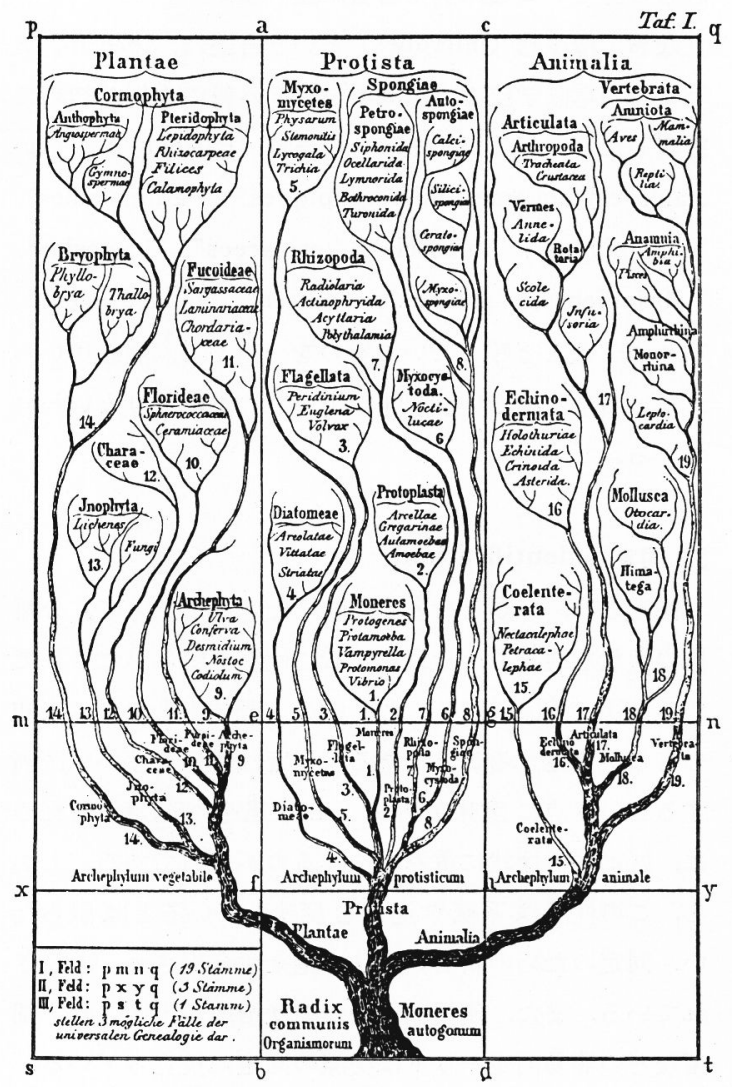

図 1-Haeckel(3) による生物の系統樹 (1866) tionship）を意味し，動物や植物ではその関係は化石の 地質学的研究, 交雑, 個体発生の研究などから考察され ている. そして，時間のパラメータが導入されているの が特徴である. しかし、これらの研究方法が適用できな い微生物, 特に細菌にあっては, 進化的関係は推定の域 を脱していなかった. 1866 年 Haeckel(3) は, 生物界に 動物界, 植物界の他に, 原生生物界 (Protista) を設け, ここに体制の比較的簡単な生物を含めた．彼の示した系 統樹（図 1）からわかるように，この界には Moneres (これについては後に述べる), Protoplasta (有殸アメー バの Arcella, 有頭類原生動物の Gregarina, Amoebae などが含まれる), Flagellata (鞭毛藻類), Diatomeae (珪 藻類), Myxomycetes (変形菌類), Myxocystoda (Noctiluca [夜光虫] が含まれている), Rhizopoda（根 足虫類), および Spongiae (現在の Porifera, 海綿動 物）が含まれている. Moneres は Protista のなかで最 も古い生物と考光られていたようで, Protogenes, Protomoeba, Vanpyrella, Protomonas, お。び Vibrioの 学名が記載されている. しかし、これらの学名のらち Vibrio を除いて岩波生物学辞典第 3 版 (1983 年) ${ }^{(4)}$ には 見いだせない。

Vibrio は細菌の学名として知られているが，もとも とは 1773 年 Müller が Infusoria (滴虫類, 㵶毛虫類 [Ciliata]ともいう〔岩波生物学辞典第 3 版】) に与六た 学名である. 彼が記載したVibrio の種のなかに細菌の 形態を示すものがあったためか, 後にこの属は細菌学の 分野で用いられ, Vibrio synthathus という種も報告さ れた。この種は 1984 年創設されたPseudomonas に移

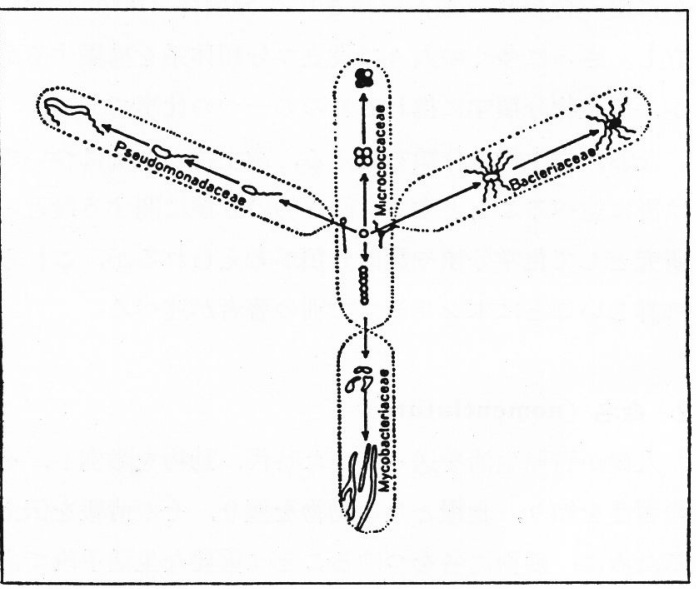

図 2『Kluyver と van $\mathrm{Niel}^{(6)}$ による細菌の進化 (1936) 
された. Hugh ${ }^{(5)}$ は, 1854 年以前に報告され, 細菌に適 用されたVibrio の種は他の属に同定されるか，または 同定できないものであると述べている. 一方，コレラの 起因菌の Vibrio cholerae は 1884 年 Pacini により記 載されたもので，しっかりとした文献上の記録があり， 現在細菌のVibrio 属の命名者は Pacini で, V.cholerae はこの属の基準種となっている. Protista にはこの ようにいろいろの生物が含まれており，Vibrio にいた っては原生動物か細菌かまだ十分に区別できない頃のこ とである.

な特, Plantae のなかに fungi と いら言葉がみられる，体制の簡単な 生物を動物・植物から独立させたこ とは卓見であるが，微生物といら言 葉が用いられたのが 1878 年のこと であるから，この時代には現在の微 生物という概念はまだ確立されて和 らず, Protista すなおち微生物とは い党なかったと思われるましてや その系統は議論の外にあったのでは あるまいか。

1800 年代の後半から 1900 年代の 前半に細菌学は著しい発展をとげ, 人拈よび動・植物の病原菌としての 研究，乳酸発酵や酢酸発酵のような 応用の研究, 土壤中の細菌の活動, また生理・生化学的研究から, 細菌 の類縁関係 (relationship) にも興味 がもたれ，1936 年にKluyver と van $\mathrm{Niel}^{(6)}$ は細菌の形態的特徴と生理 · 生化学的特徵に基づく分類体系を報 告した.このなかで彼らは, 図2 に 示すように細菌は形態の単純な球菌 から極鞭毛を有する Pseudomonadaceae の系統に, 周鞭毛をもつ Bacteriaceaeの系統, また形態の複雑な Mycobacteriaceae の系統に,そして， 球菌は四連球菌から八連球菌へと進 化したと考えた. 1941 年には Stanier と van $\mathrm{Niel}^{(7)}$ はこれをやや改変 し，図３のうな系統を提案した.
その後, 1969 年にWhittaker ${ }^{(8)}$ は，生物をとの体制 そエネルギーの獲得機構から図 4 に示すように5つの界 に分類し，原核生物である細菌と藍藻をとの体制から Monera として独立させ，新たに菌類界を設けたこのの five-kingdom system は現在の微生物学が対象としてい る微生物を理解するら党で役立つが，時間のパラメータ が考慮されていない。

最近の DNA，RNA，蛋白質などの情報高分子に関す る研究は, 生物の類縁を分子のレベルで研究する途を開 き，細菌の進化についても新しい展開がみられるよらに

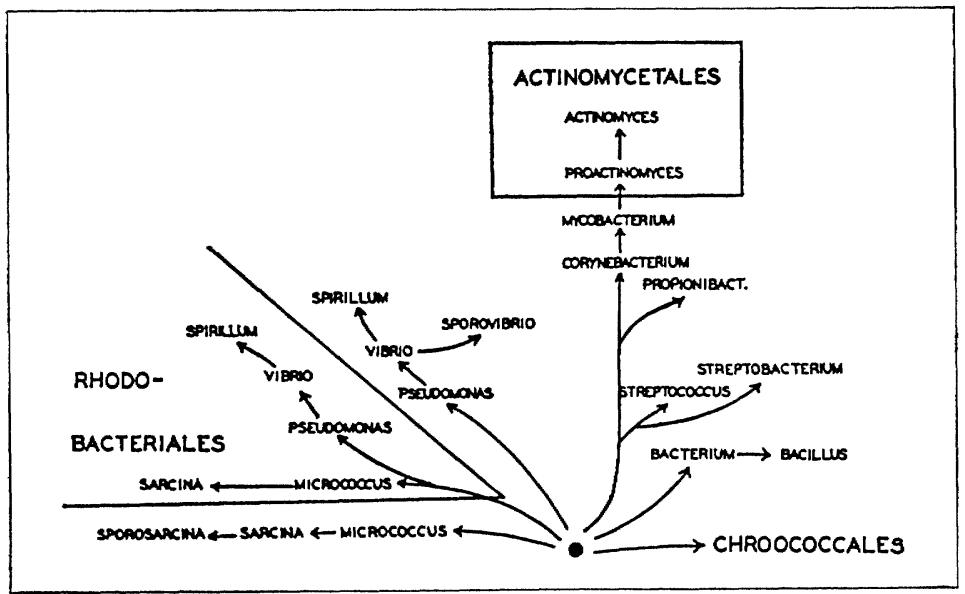

図 3曰Kluyver と van Niel(6) の細菌の進化を改変した Stanier と van $\mathrm{Niel}^{(7)}$ による細菌の進化 (1941)

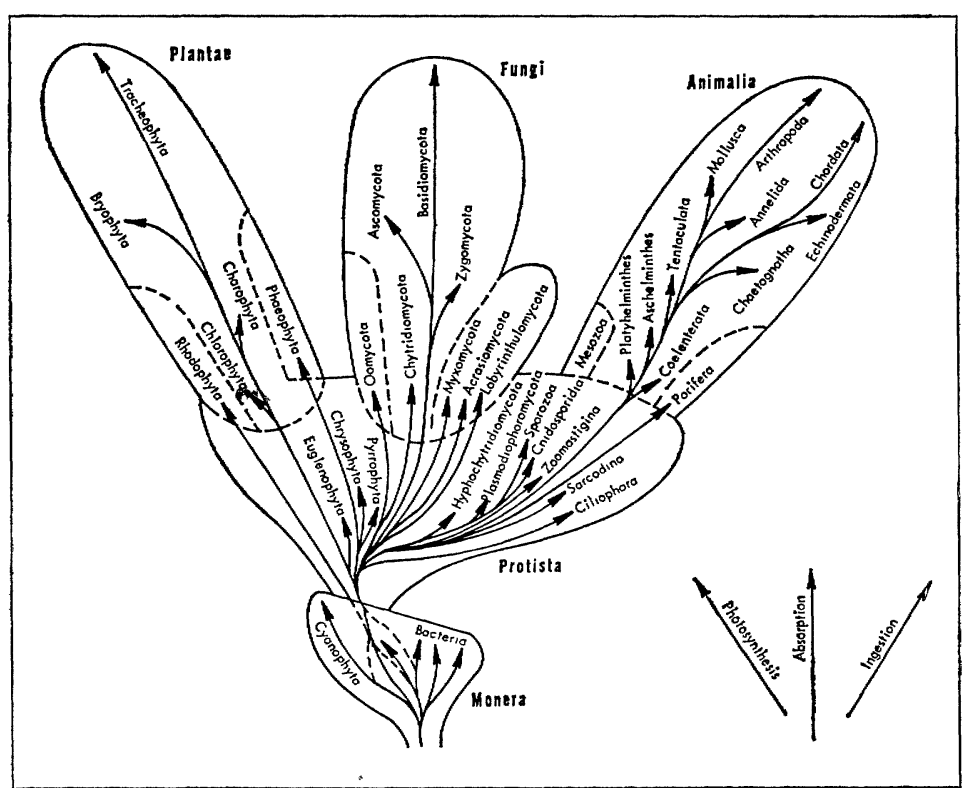

図 4 m Whittaker ${ }^{(8)}$ による生物の5 界 (1969) 


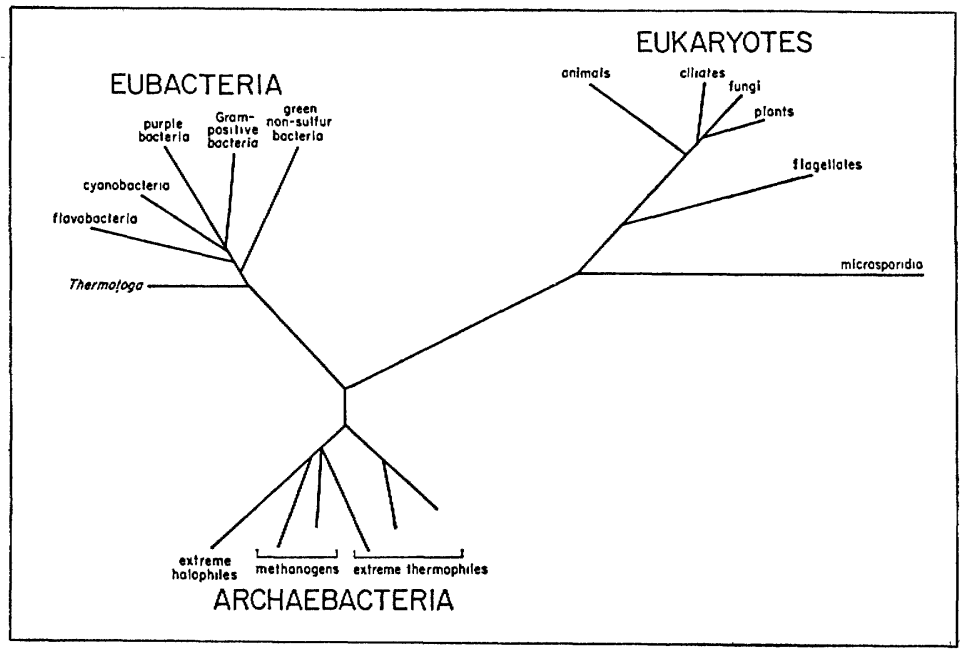

図 5曰Woese (9) $^{(9)}$ にる rRNA のカタログ法, シークエンスなどに基づく 生物の系統 (1987)

なった.すなわら, Woese らは細菌の $16 \mathrm{~S}$ リボソーム RNA (16 S rRNA) のカタログ法による研究から ${ }^{(9)}$ ，メ タン生成細菌は通常の細菌より進化的汇古い細菌である と考え, Archaebacteria (古細菌) といら概念を提案し, 種々の情報を考慮し, 図5のよらな系統樹を発表した.

しかし，彼のいら古細菌は $16 \mathrm{~S}$ rRNA のカタログ法に よる比較で，いわゆる真正細菌（Eubacteria）と連結す る点が最も離れていることを主な根拠としており, 正確 にいえば時間のパラメーターはないとい方よう。

一方, Hori と Osawa は, すべての生物に認められる $5 \mathrm{~S}$ リボソーム RNA (5 S rRNA) のシークエンスに注

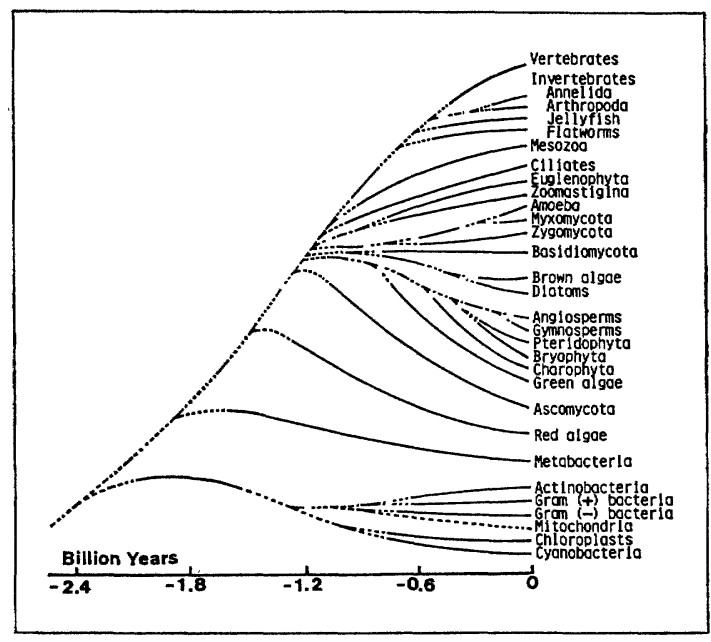

図 6ロHori と Osawa(10) による 5S rRNA シークエ ンスに基づく生物の系統（1987）
目し，これに基づく生物の進化関係 を報告した ${ }^{(10)}$ 。すなわち，5S rRNA の一次配列を 2 種間のすべての組み 合わせで比較して， ヌクレオチドの 置換数をかぞえ，相違度をるとめ， 木村の中立説に基づき進 化 距離 （ $K_{\text {nuc }}$ )を計算し， $K_{\text {nuc }}$ の小さい順 に並べて系統樹作成した，図6は 352 の 5 rRNA のシークエンスか ら求められた系統樹で, 細菌からヒ トまで $5 \mathrm{~S}$ rRNA のヌクレオチド の置換率は一定であると仮定し，時 間のパラメーターは酵母とヒトが分 岐した後の時間（12 億年)を基隼に している.この系統樹が示すように, 化石の記録がなく，有性世代のない細菌にあっても，分 子のレベルで進化的関係が論じられるようになったこと は特筆できょう，堀と大沢によれば，Woese のいう古

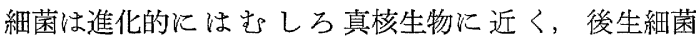
(Metabacteria) と言うべきものであると主張している.

また，桿菌であるArthrobacter と球菌である Micrococcus とは系統的汇近い関係にあり ${ }^{(11)}$ ，このことは16 S rRNA のカタログ法でも同じ結果が得られている. 筆者らは, $5 \mathrm{~S}$ rRNA のシークエンスから運動性球菌の Planococcus Marinococcus が運動性有胞子球菌の Sporosarcina とともに有胞子桿菌のBacillus の一部と 近い関係にあることを認めている (未発表).これらの データは, 細菌の進化について単純な形態から複雑な形 態に変化したという Kluyver と van N1el ${ }^{(6)}$ の説が当て はまらないことを物語っている。

グラム陰性細菌についても，16S rRNA のカタログ 法や $5 \mathrm{~S}$ rRNA のシークエンスの点からその系統が論 ごられている．筆者らはメタノール資化性細菌の一つで ある Protomonas が 5 S rRNA のシークェンスから大 腸菌や Pseudomonas などと異なるクラスターに属し， またメタン資化性細菌の一部はProtomonas などのメ タノール資化性細菌と系統的に異なることを認めている (未発表).

これらの研究は, 細胞形態や生理・生化学的性状に基 づいてなされてきたこれまでの微生物分類学の研究に大 きな影響を与兄ることとなり，次に述べるような問題が 
提起された。

\section{国際細菌分類命名委員会特別部会の報告 ${ }^{(12)}$}

最近の微生物，特に細菌に関する研究は，その相互関 係を分子のレベルで比較し，さらに時間のパラメーター で進化や系統を論ずることを可能にした，そこで，国 際細菌分類命名委員会は，情報高分子に基づく系統分類 学 (semantide-based phylogeneic taxonomy) 之伝統的 な表現形質に基づく細菌分類学 (traditional phenotypebased systematics）との調整を計るため，特別部会を設 け，この問題を討議した．委員会のメンバーは国際細菌 分類命名委員会から何人かが加わっているが，多くは長 年化学分類の分野で研究を続けてきた研究者である．最 近，その報告書が公表された。このことは必然的に微生 物分類学に大きな影響を与えると思われるので，次にそ の要点を述べることとする．特別部会の意見と筆者の考 壳が混乱しないように，注意を払ったつもりであるが， 誤解を招くような点があれば，筆者の責任である。なお， 特別部会報告のなかで強調するところはイタリック体で 示してあるが，本稿ではアンダーラインで示した.

この報告の前文で “数值分類学と情報高分子に基づく 進化の研究から，かなり主観的なところから出発した細 菌分類学も次第に客観的となり，このことは命名上の変 更を余儀なくさせているそとて，現在の命名体系は階 層的な分類学上の分割がまだ㖟昧な時代化作られたもの なので, 新しい分類学の理解に基づいてこの体系を再検 討しなければならなくなった”と述べている，をして， 問題点として, 系統 (phylogenetic), 記載 (descriptive)，鑑別（diagnosis）などをあげ，それぞれを定義 したら壳で，次の結論と勧告を述べている。

\section{階層分類学 (Hierarchical taxonomy)}

細菌分類学は先に述べたように，最小単位の種から次 第に上位分類群にまとめていく階層的な考えをとり，そ して一つのシステムが作られる. この委員会は，“公的 で総合的な一つのシステムが分類学にとって理想的のも のであり，特定な細菌を鑑別するためのグルーピングが あれば第二のシステムは必要ではない”と述べている。 また，“完全な DNA のシークエンスが系統を決定する 基準であり, 分類学は系統に基づき，命名は系統に一致 (反映)せねばならないそとて，リボソーム RNA シス
トロン以外の情報高分子についても活発な研究を続ける べきである”と勧告している. “本質的な化学分類学的 データ特よびシークエンスデータがないよらな状態で階 層的な分類群の提案をすべきでない”とも述べている. しかし，細菌の系統はまだ十分わかっていないので，化 学分類学上のデータの重要性も指摘し, 分類群について 次のよらな見解を述べている。これは，これからの細菌 分類学が系統分類学を指向し，命名もその結果を反映す ベきであることを示していると考えられる。しかし，実 際上菌株の同定ができなければ無意味であるので，その 点についても配慮している

種 (Species), 亜種 (Subspecies), および亜種以外 のカテゴリー

種の定義は細菌分類学上種々論議のあるところである が，この委員会では次のように述べている，すなわち， “種は現在系統的に定義でさる唯一の分類学上の単位で ある.そして，実際上，DNA の相同性は DNA のシー クエンスを知るスタンダードであり，現時点で最も適用 可能な手法である。種は系統的にほぼ $70 \%$ またはとれ

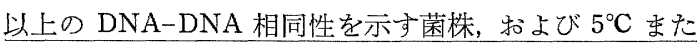
はそれ以下の $\Delta T_{\mathrm{m}}$ をもつ菌株を含むものと定義され， DNA-DNA 相同性の值と $\Delta T_{\mathrm{m}}$ の 2 つの值を考慮しな くてはならない，表現形質はこの定義に一致すべきであ り，系統的な種の概念を無視することはわずかな例外を 除いて認められない，既知の表現形質に基づいて他の遺 伝的種（genospecies）と区别できない遺伝的種は，それ が表現形質によって区別できるまで命名すべきでないと いらことを勧告する”と述べている.この種の定義はか なり独断的であり, 今後微生物の種の定義をめぐり大き な論議を呼ぶものと思われる。このような定義をした背 景には，腸内細菌をはじめ膨大な DNA-DNA 相同性の データの蓄積があるためであろら，一方，一部の細菌の 進化論者が細菌学の歴史を無視した発表をしているのに 対し，表現形質による同定ができなければ，害用上意味 がないことを，明確に指摘していることは注目すべきこ とである．委員会が分類と同定の調和を図る点で，いか に努力したかがらかがえる。

亜種については，遺伝的には近縁であるが，表現形質 で異なる細菌に用いることができるまた，DNA の相 同性から亜種の概念は有効であり, “有用性（utility）の みに基づく変種の概念（variety concept）とは区別でき 
る”と述べている. しかし，“互種の定義についてはさら に詳しい指針が必要である”と指摘している.

属については, “細菌分類学上その存在の必要性を認 めているが，現在のところ満足すべき系統的な定義はな い”としている. そして, 他の上位分類群と同じょうに, “属の定義の範囲は属によって異なってもよい”と述べ ている. 科については, “化学分類学的データと DNA 相同性，要るいはンークェンスデータの均一性が認めら れる限り残すことができる”としている．科以上の分類 群についても触れているが，その姿勢はそれほぞ積極的 ではない。

\section{命名 (Nomenclature)}

細菌の命名は，細菌命名規約に則っているか，いない かといら問題であるが，これをめぐり，さまざまな意見 がある. 委員会は, 厳密な系統的類縁港づく二命名法 と実際上の二命名法の種レベルに拈ける矛盾について種 種の角度から検討した結果, 次の勧告を作成した.

“命名は可能な限り遺伝的類縁を反映せ齐ばならない. 例外は, nomen periculosum の使用を認めた細菌分類命 名裁定委員会の議事録 $7 \mathrm{i}$ (Int. J. Syst. Bacteriol., 37，85-87 (1987)) に收録されている規則 56 a の修正に より是認されるものだけである”（註：nomen periculosum [英語の periculous name で，をだ日本語訳はな い.ここでは危険名として打くコは健康, 生命, あるい はその両者を危うくするか，経済的に重大な結果をもた らすようなものに適用される。たと兊ば、ペスト菌は Yersinia pseudotuberculosis subsp. pestis であったが, 命名上の問題と実際上〔医療上〕の混乱をさけるため にこの亜種名は危険名として否定され，Y.pestis と， $Y$. tuberculosis が保留名として残された事例がある).“こ のような命名上の矛盾が認められた事例については，そ の情報を広く行きわたらせる機構が必要である.”最近， 医学, 獣医学, 農業, 工業などの分野で重要な性状がプ ラスミド，ファージなどの核外遺伝質によりコードされ ていることが知られているが，これらの有用性を示す補 助的な用語は細菌命名規約飞拘束されない。“不適当な命 名に関し，次のことを勧告する.主な綱のグルーピング そついて公式な命名が必要である.グラム陽性細菌は現 在定義されているように Firmicutes とすべきである。 Purple bacteria といら言葉は光合成細菌以外のるのを 含んでいるので混乱を招く、これが正式の名を決めなく
てはならないという理由である.”

\section{その他}

細菌の系統が明らかになるに従い, 生理・生化学的性 質で分類されてきた細菌の属の位置づけが問題となって いる. 委員会は次のように述べている.

"the purple photosynthetic bacteria and relatives といらような主要な系統的な分類群を含む細菌を現状の 分類学に即して再構成するには，かなりの問題が予測さ れる.この細菌のなかには伝統的なグラム陰性細菌のほ とんどの属, すなわち，光合成細菌と化学合成細菌の 属, purple bacteria の $\alpha, \beta, \gamma$, および $\delta$ が含まれて いる. したがって，重要な作業はそれぞれのグループ内 に存在する多様な代謝形式をるつ細菌の系統を, 分類学 上拉よび命名上解決する手段を作り上げることである. そして, 最初の作業は系統的な分類群のなかの属の定義 と属の限界を明らかにし，属に種の基隼株を含ませるこ とである. 国際細菌分類命名委員会に特別部会を設立 し，この問題の研究を委嘱するよう勧告する”.

最近，2種以上の微生物が混在したます特殊な働きを 示すが，それぞれを純粋に培養ができない事例が報告さ れている.このことは当然細菌命名規約にも関係する.

また，生態学の見地からも細菌分類学の発展が望まれる ので, 特別部会は次のような見解を示している.すなわ ち, “調查研究は培着できない (noncultivable)，岁るい は培着が注とんどできない細菌の生育掞よび鑑別上の問 題を解決することを目指すべきである，また，他の生物 から分離して培養できない細菌 (organisms not cultivable axenically) で, 多生物系 (multiorganisms systems）では，培養できる集合体（consortia）の位置を明 らかにするため，細菌命名規約の改正が必要である。ま た, 生態学的見地からも細菌分類学の基本的理解が必要 となり, 分類学的研究と新しい化学分類学の指標の研究 が促進されねばならない，基礎と応用を問わず，特にバ イオテクノロジーの分野では, 微生物分類学の必要性は 大きい沈かかわらず，その認識はまだ十分ではない” と述べている，そして最後に，“委員会メンバーに共通 した意見は，系統に基づく分類体系はまた表現形質の均 一性を示さ补な゙ならない，といらことであった”，と結 えでいる. 
新しい微生物分類学は理解できないといら時点にまでき ているのではあるまいか。

微生物の研究はわれわれの生活と結びついたところか ら始まりまた顕微鏡という器具を用いなければ観察で きないこともむって，動物や植物の研究とはかなり異な った途をたどってきた。病気に関係する “徽菌”る, 納豆 の製造にかかわる “納豆菌”る同じ細菌であるという理 解㑢到達するには長い時間が必要であった。現在では, 系統的に異なる微小な生物を微生物と呼九で，バイオテ クノロジーの担い手として謳っているが，それぞれ異な る微生物がぞの点で共通であり, どの点で共通でないか といら理解についてはまだ十分とはい光ない，一方，こ の微生物は “生命のモデル”として, 近代生化学, 遺伝 学, 分子生物学の発展湏献してきた. 微生物分類学は このような背景のもと，多様な途を歩んできた。しか 乙, 最近では関連分野の研究の進展とともに微生物分類 学も次第に生物学としての色彩が濃くなってきたように も思われる. そして, 伝統的な微生物分類学々系統に基 づく新しい微生物分類学とのギャップが次第に大きくな り，それを埋めるため，国際細菌分類命名委員会特別部 会は細菌分類学に打ける問題点を指摘し，その解決を図 った。このような潮流がやがて他の微生物の分類学にも 影響を及ぽし，大きな渦となって既存の分類体系の見直 しを迫ることは必至である。微生物分類学は決して static なものではなく, 時代とともにdynamic 飞変貌し ている学問分野である.すでに，この認識がなければ,

\section{文献}

1) A. J. Kluyver: 'The microbılogist', in "Martinus Willem Beijerinck, His Life and His Work", ed. by van Iterson Jr., den Dooren de Jong and A. J. KLuyver, Science Tech. Inc., Madison, 1983, p. 99.

2) C. Jeffrey : "Biological Nomenclature", 2 nd ed., Edward Arnold, London, 1977, p. 5.

3) E. Haeckel : "Generelle Morphologie der Organısmen", Vol.2, Reimer, Berlin, 1866 (M. A. Ragan \& D. J. Chapman : "A B1ochemical Phylogeny of the Protists", Academic Press, New York, San Francisco, London, 1978, p. 1 より引用).

4）山田常雄, 前川文夫, 江上不二夫, 八杉竜一, 小関治男, 古谷雅樹, 日高敏隆 (編) : “岩波生物学辞典”, 第 3 版, 岩 波書店, 1983 .

5) R. Hugh : Int. Bull. Bacteriol. Nomen. Taxon., 14, 87 (1964).

6) A. J. Kluyver \& C. B. van Niel : Zenralbl. Bakterien. Parasitenk. Abt II., 94, 369 (1936).

7) R. Y. Stanier \& C. B van Niel : J. Bacteriol., 42, 437 (1941).

8) R. H. Whittaker: Science, 163, 150 (1969).

9) C. R. Woese : Microbiol. Rev., 51, 221 (1987) (Woese 之彼の共同研究者による報告は多いので最近の総説をあげ た).

10) H. Horı \& S. Osawa : Mol. Biol. Evol., 4, 445 (1987) (堀と大沢汇よる報告は多いので最新の報告をあげた).

11) Y.-H. Park, H. Hori, K. Suzuki, S. Osawa \& K. Komagata : J. Bacteriol., 169, 1801 (1987).

12) L. G. Wayne, D. J. Brenner, R. R. Colwell, P. A. D. Gr1mont, O. Kandler, M. I. Krichevsky, L. H. Moore, W. E. C. Moore, R. G. E. Murray, E. Stackebrandt, M.P. Starr \& H. G. Trüper : Int. J. Syst. Bacteriol., 37, 453 (1987).

\section{プロ フ ィ ル}

藤井 義晴 (Yoshiharu Fujii) 昭和30 年 1 月 18 日生 <略歴 $>$ 昭和 52 年京都大学 農学部食品工学科卒業 $/ 56$ 年同大学大学 院農学研究科博士課程中退／同年農林水 産省農業技術研究所勤務 $/ 58$ 年同省農業 環境技術研究所勤務，現在にいたるく研 究テーマと抱負〉他感作用（アレロパシ 一物質)の検索と機能の解明.アレロパ シーを実証し，農業生産に役立て，環境 と調和したクリーンな農業をめざしたい、 く趣味>クラシック音楽 (バッハ, モー ツフルト) 鑑賞

宮 开 潔 (Kiyoshi Miyai) 昭和 4 年 6 月 2 日生<略歴>昭和 30 年大阪大学医 学部医学科卒業 $/ 35$ 年同大学大学院医学 研究科修了 (医博) / 同年同医学部助手 (内科学第一) $/ 44$ 年同講師 (中央臨床検 查部) $/ 47$ 年同助教授 $/ 51$ 年同教授 $/ 55$
年同教授(臨床検査診断学)，現在にいた る.この間，38〜 40年米国コロンビア大 学留学く研究テーマと抱負〉予防医学検 查, 内分泌の分子遺伝学 <趣味 $>$ 音楽鑑 賞

右巻き(ペソネーム) 某大学, 某 学部, 化学教室所属. 当人が左巻きでな いことを望みつつ，分子レベルでキラリ ティーや右巻き DNA の化学を研究

宮川 都吉 (Tokichi Miyakawa) Vol 21, No.3, p. 167 参照

宮 本 拓 (Taku Miyamoto) 昭和24 年 9 月 10 日生<略歴>昭和 47 年岡山大学 農学部畜産学科卒業 $/ 49$ 年同大学大学院 農学研究科修士課程修了 $/ 50$ 年同農学部 助手, 現在にいたる. 農博く研究テーマ
之抱負 $>$ 乳酸菌の代謝機能の開発と食品 加工への応用く趣味>スポーツ観戦, 团 暮

四津 まり（Mari Yotsu） 昭和36年 4 月19日生<略歷>昭和59年東北大学農学 部食糧化学科卒業 $/ 59$ 年同学部文部技 官，現在にいたるく研究テーマと抱負〉 現在テトロドトキシンの生合成に最す興 味を持っているが，化学的な基礎と現象 を分析する能力を身につけたいと思う く趣味>ハイキング, サイクリングなど 戸外へ出ること.ピアノを弾くこと

盧 義 発 $\left(\mathrm{Y}_{1}-\mathrm{Fa}, \mathrm{Lu}\right)$ 昭和27年 4 月 10 日生<略歴>昭和63年九州大学大学院 農学研究科食糧化学工学専攻修了/同年 台湾行政院衛生署薬物食品検験局勤務, 現在にいたる 